\title{
Erratum Xu T. et al. Cloning and Expression Analysis of MEP Pathway Enzyme-encoding Genes in Osmanthus fragrans. Genes 2016, 7, 78
}

\author{
Chen $\mathrm{Xu}{ }^{1}$, Huogen $\mathrm{Li}^{2}$, Xiulian Yang ${ }^{1}$, Chunsun $\mathrm{Gu}^{3}$, Hongna $\mathrm{Mu}^{4}{ }^{4}$, Yuanzheng Yue ${ }^{1}$ and \\ Lianggui Wang ${ }^{1, *}$ \\ 1 College of Landscape Architecture, Nanjing Forestry University, Nanjing 210037, China; \\ xc127@foxmail.com (C.X.); yangxl339@sina.com (X.Y.); yuanzhengyue@163.com (Y.Y.) \\ 2 Key Laboratory of Forest Genetics \& Gene Engineering of the Ministry of Education, \\ Nanjing Forestry University, Nanjing 210037, China; hgli@njfu.edu.cn \\ 3 Institute of Botany, Jiangsu Province and Chinese Academy of Sciences, Nanjing 210014, China; \\ chunsungu@126.com \\ 4 College of Horticulture and Gardening, Yangtze University, Jingzhou 434025, China; hongnamu@163.com \\ * Correspondence: wlg@njfu.com.cn; Tel./Fax: +86-25-8542-7770
}

Received: 25 January 2017; Accepted: 25 January 2017; Published: 2 February 2017

The authors wish to make the following correction to their paper [1]. The name of the second author was misspelt. The correct name should be "Huogen Li". The authors would like to apologize for any inconvenience caused. The change does not affect the scientific results. The manuscript will be updated and the original will remain online on the article webpage.

\section{Reference}

1. Xu, C.; Li, H.; Yang, X.; Gu, C.; Mu, H.; Yue, Y.; Wang, L. Cloning and Expression Analysis of MEP Pathway Enzyme-encoding Genes in Osmanthus fragrans. Genes 2016, 7, 78. [CrossRef] [PubMed]

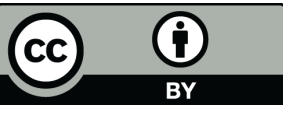

(C) 2017 by the authors; licensee MDPI, Basel, Switzerland. This article is an open access article distributed under the terms and conditions of the Creative Commons Attribution (CC BY) license (http:/ / creativecommons.org/licenses/by/4.0/). 